\title{
A set of motives to unite them all?
}

\author{
Article
}

Accepted Version

Cuervo-Cazurra, A. and Narula, R. (2015) A set of motives to unite them all? Multinational Business Review, 23 (1). pp. 214. ISSN 1525-383X doi: https://doi.org/10.1108/MBR-032015-0010 Available at https://centaur.reading.ac.uk/48143/

It is advisable to refer to the publisher's version if you intend to cite from the work. See Guidance on citing.

Published version at: http://dx.doi.org/10.1108/MBR-03-2015-0010

To link to this article DOI: http://dx.doi.org/10.1108/MBR-03-2015-0010

Publisher: Emerald

All outputs in CentAUR are protected by Intellectual Property Rights law, including copyright law. Copyright and IPR is retained by the creators or other copyright holders. Terms and conditions for use of this material are defined in the End User Agreement.

\section{www.reading.ac.uk/centaur}

\section{CentAUR}

Central Archive at the University of Reading

Reading's research outputs online 


\section{A set of motives to unite them all? Revisiting the principles and typology of internationalization motives}

\section{Introduction}

This debate forum in Multinational Business Review derives in part from a special session at the 2013 Reading-UNCTAD conference, where we asked the panelists to answer the question, "Does the classification of multinational enterprises (MNEs) motives still make sense?" As with all academic enquiries, there was no obvious and simple response. Indeed, as the discussion we held then and as the contributors to this forum note, there has been a wide variety of motives and classification schemes proposed over the years.

Given that the Reading conferences (and a good number of the participants) demonstrate a bias towards atheoretical approaches associated with the 'Reading School', there was a natural drift towards redefining the question as: 'Dunning's classification of motives: Do we need to revisit it?' One would think that this gives a clear and fairly concrete mandate for discussion, but as van Tulder (2015, in this issue) observes, although Dunning's view is now almost paradigmatic, his opinion of the 'main' motives changed over time. Dunning offered a much more comprehensive list (Dunning, 1993), before emphasizing the now much-cited four 'seeking' motives (market-, resource-, factor- and strategic asset-seeking) (Dunning, 1993; Dunning and Lundan, 2008). Although his prior work included other motives (e.g., bandwagon effects, escape investments, passive investments, support investments, tradesupportive investments...), these other motives became regarded as being of secondary value; they are not even mentioned in much of the subsequent analyses of motives by other scholars.

Of course, there are alternative classifications of internationalization motives (see CuervoCazurra et al., 2015 in this issue; van Tulder, 2015 in this issue). That the wider academic community can come up with several different alternative classifications (to which this 
debate forum contributes yet more) leads to several questions: Why are there so many options, and why has the field of international business largely chosen to adopt a simple fourway classification? Why had Dunning decided to emphasize four instead of a dozen? Had the world become simpler with time, and had the activities and strategies of MNEs become more homogenous, that just four motives sufficed for most of our analytical needs? Do these four primary internationalization motives still meet our needs?

\section{The genesis of internationalization motives and the need for extending them}

It is always useful to step back and consider the setting in which these questions were first asked and answered, and to understand the context in which earlier generations of international business (IB) scholars addressed them. Dunning's internationalization motives whichever version you prefer - were not intended as a stand-alone theoretical device, but as an appendage to the internationalization literature, and specifically towards understanding the behavior not of MNEs in general, but of their foreign direct investment (FDI) activities in particular (Benito, 2015 in this issue). That is it to say, Dunning answered the question: what are their motives to undertake fully-internal production in a foreign location? Note that Dunning's work intentionally referred to 'production' and not 'activities', because the initial novelty of FDI (as opposed to trade) was the internationalization of production.

Indeed, Dunning initially used 'motives' and 'types' of foreign production as synonyms, and one of the earlier references [1] to these 'types' goes back to the Kojima-Reading School debate, and the various participants of that exchange of papers. Kojima (1978) referred to two types (motives) of FDI: import-substituting (trade-displacing) and offshore or exportplatform (trade-creating) types of investment. The popularity of the concept took off in IB at that point, partly as a response to his unfortunate dichotomy. A close reading of contributions 
to Pitelis and Sugden (both the 1991 and the 2000 edition) indicates a strong interest by a number of authors towards understanding the different types of FDI.

In an earlier contribution, Dunning (1988) proposed three main motives: Market seeking (import substituting), Resource seeking (supply oriented), and Efficiency seeking (rationalized investment). Dunning (1993) offers a more complete list of motives, which we have listed in Table I, later largely duplicated in Dunning and Lundan (2008) (although the discussion on asset-seeking was revised). It is interesting to note that in Dunning (1993) there was considerable overlap between asset-seeking and resource-seeking. He notes that "The third type of resource-seeking FDI is prompted by the need of firms to acquire technological capability, management or marketing expertise and organizational skills" (p.57), although this overlap is corrected in subsequent work.

The last five motives listed in Table I are classified as 'other motives', implying that he considered them to be secondary [2], and for some reason have largely been ignored by the IB community. However, a closer reading of these indicate that motives such as 'escape investments' are of growing importance, and studies of emerging country MNEs recognize that there is considerable EMNE activity promoted by the need to avoid institutional voids, a category that fits well with 'escape investments' (Cuervo-Cazurra and Ramamurti, 2014). Likewise, a considerable amount of FDI continues to be undertaken to maintain and support trade. Trade is still important, and in fact 80 per cent of all trade remains in the hands of MNEs. The growth of service MNE activity has surely created the need for us to pay closer attention to 'finance-supportive investments', because banks and insurance companies require a local presence for regulatory reasons. 
Table I. Updating the nine Dunning internationalization motives

\begin{tabular}{|c|c|c|c|}
\hline $\begin{array}{l}\text { The } \\
\text { "Nine Rings } \\
\text { (motives) for } \\
\text { Mortal Men" } \\
\text { and their } \\
\text { MNEs }\end{array}$ & $\begin{array}{l}\text { Types } \\
\text { (adapted from } \\
\text { Dunning, } \\
\text { 1993) }\end{array}$ & $\begin{array}{l}\text { Objectives/Motives (inspired by and updated from } \\
\text { Dunning, 1993) }\end{array}$ & $\begin{array}{l}\text { The } \\
\text { Cuervo- } \\
\text { Cazurra et al. } \\
\text { motives (2015 } \\
\text { in this issue) }\end{array}$ \\
\hline 1 & $\begin{array}{l}\text { Natur } \\
\text { al resource } \\
\text { seeking }\end{array}$ & $\begin{array}{l}\text { To acquire particular and specific resources of a } \\
\text { higher quality at a lower real cost than could be obtained in } \\
\text { their home country (e.g. physical resources, un-skilled (or } \\
\text { semi-skilled) labor, technological/managerial expertise, etc.) }\end{array}$ & Better' 'Buy \\
\hline 2 & $\begin{array}{l}\text { Marke } \\
\text { t seeking }\end{array}$ & $\begin{array}{l}\text { To supply goods or services to a particular country } \\
\text { or region (from existing markets to new markets) }\end{array}$ & More' 'Sell \\
\hline 3 & $\begin{array}{l}\text { Effici } \\
\text { ency seeking }\end{array}$ & $\begin{array}{l}\text { To rationalize the structure of established resource- } \\
\text { based or market seeking investment in such a way that the } \\
\text { investing firm can gain from the common governance of } \\
\text { geographically dispersed activities (e.g. economies of scale } \\
\text { and scope) }\end{array}$ & $\begin{array}{l}\text { 'Buy } \\
\text { Better' and } \\
\text { 'Sell More' }\end{array}$ \\
\hline 4 & $\begin{array}{lr} & \text { Strate } \\
\text { gic } & \text { asset } \\
\text { seeking } & \end{array}$ & $\begin{array}{l}\text { To promote long-term strategic objectives - } \\
\text { especially that of sustaining or advancing global } \\
\text { competitiveness (e.g. augmentation of global portfolio of } \\
\text { physical assets and human competences, which they perceive } \\
\text { will either sustain or strengthen their ownership-specific } \\
\text { advantages or weaken those of competitors) }\end{array}$ & 'Upgr \\
\hline 5 & $\begin{array}{l}\text { Escap } \\
\text { e investment }\end{array}$ & $\begin{array}{l}\text { To escape restrictive legislation, institutional voids, } \\
\text { or macro-organizational policies by home governments (e.g. } \\
\text { round-tripping investment, escaping from high levels of } \\
\text { taxation or austere environmental regulation, etc.) }\end{array}$ & 'Escap \\
\hline 6 & $\begin{array}{l}\text { Trade- } \\
\text { supportive } \\
\text { investment }\end{array}$ & $\begin{array}{l}\text { To promote and facilitate the exports and imports of } \\
\text { goods and services from the investing (or other) firm }\end{array}$ & $\begin{array}{l}\text { 'Buy } \\
\text { Better' and } \\
\text { 'Sell More' }\end{array}$ \\
\hline 7 & $\begin{array}{l}\text { Finan } \\
\text { ce-supportive } \\
\text { investment }\end{array}$ & $\begin{array}{l}\text { To support and assist in the purchasing of foreign- } \\
\text { produced goods and services from investing (or other) firm } \\
\text { To establish domicile in specific location for } \\
\text { regulatory and tax reasons }\end{array}$ & $\begin{array}{l}\text { 'Buy } \\
\text { Better' and } \\
\text { 'Sell More' }\end{array}$ \\
\hline 8 & $\begin{array}{l}\text { Mana } \\
\text { gement- } \\
\text { supportive } \\
\text { investment }\end{array}$ & $\begin{array}{l}\text { To support the control and coordination function on } \\
\text { behalf of MNE headquarters (e.g. regional office, branch } \\
\text { offices) }\end{array}$ & 'Upgr \\
\hline 9 & $\begin{array}{l}\text { Passiv } \\
\text { e investment }\end{array}$ & $\begin{array}{l}\text { To arbitrage by buying and selling firms or assets } \\
\text { with some involvement of direct managerial inputs (e.g. } \\
\text { private equity capital firm, asset stripping, etc.) }\end{array}$ & $\begin{array}{l}\text { 'Buy } \\
\text { Better' and } \\
\text { 'Sell More' }\end{array}$ \\
\hline
\end{tabular}

This brief review of John Dunning's understanding of motives indicates that the motives, like the rings in Tolkien's world, can be changed, in some cases cast away, and occasionally even destroyed in the fires of Mount Doom if needed. Their modification is driven by a twin set of forces. First, technological and institutional advances in the world economy lead to new 
developments in the way in which firms organize themselves as MNEs, and the degree of heterogeneity of motives is by no means diminished, which leads to the need to adapt arguments to reality. Second, John Dunning made revisions at various points in time to his list of motives in response to the changes in MNE activity. These 'picks' - as several contributions in this issue of MBR note - were deductive and atheoretical. There is no reason to believe that the choice of 'main' and 'secondary' motives is not in need of an update. As the world has changed, so has the IB literature.

Globalization changed the world in the last 30 years...

The world has not stayed in the same place in the last 30 years. We live in a very different environment, as much-discussed in the globalization literature (see Held et al., 1999, Narula 2003), with shrinking economic distance, lower transaction costs, and de facto economic integration. In a purely IB world, there are a variety of new actors from SMEs to bornglobals, and from private equity to state-controlled enterprises and sovereign wealth funds. There are new modes of governance where full control is exerted without ownership and through non-equity agreements. MNE activity is not only about FDI, because ownership is no longer a pre-condition for control. Thanks to bilateral and multilateral agreements, goods and services that were considered non-tradeables are no longer so, sectors, countries and markets in which MNEs were not permitted access are now available.

We also have MNEs from all types of countries, from a variety of new sectors that would hitherto have been home-bound. The concept of nationality and identity has strayed considerably since Robert Reich's stirring discussion of interdependencies and linkages in his article entitled, "Who is 'Us"'(Reich 1990), and although nationalities may still matter, boundaries of firms and nations are porous and imprecise (Narula and Dunning, 2010). The 
world - at least from an IB perspective - has got so much more complicated that it seems intuitive that less should certainly not be more.

Globalization has meant that - for instance, because of changes in the trade and investment regulatory framework in a WTO-world, as well as capabilities that allow us to coordinate activities more effectively - industries such as utilities, insurance and banking can expand abroad. Other sectors such as back-office processing, software, call centers, were rarely subcontracted to providers in other countries prior to the last fifteen years. These and other new sectors require us to think in different ways. Fast-evolving service sectors where customer interaction is key to their core activity are obviously more systematically engaged in learning as part of their raison d'être. This is what van Tulder (2015, in this issue) refers to as sector-intrinsic motives.

However, greater heterogeneity in types of actors engaged in cross-border activities does not necessarily mean that there should be more internationalization motives. A good theory should be able to explain the behavior of economic actors; most principles of economics and sociology still hold; firms still seek to generate profits; companies are still faced with risks of internationalizing, and many still fail.

\section{... and the world of ideas changed with it}

It might seem to the younger generation of IB scholars that this is stating the obvious, but the context in which these ideas about motives were first broached is important for understanding them. The initial motives were discussed at a time of limited economic integration. In much of post-WWII era, and perhaps until the early 1990s, the idea of ongoing, intensive and sustained MNE activities was unusual. FDI was an uncommon phenomenon and served the 
purpose of enhancing trade, and indeed FDI was seen either as a substitute or a complement for trade (illustrated by the rather large number of studies during the 1980s and 1990s that asked: 'are FDI and trade substitutes or complements?'). The idea of complex cross-border configurations and the MNE as an integral part of the socio-economic milieu with a variety of dispersed activities were more science fiction than fact. Even in the early 1990s, IB was associated with large MNEs with specific characteristics, such as a strong centripetal tendency, and single, all-powerful headquarters, and with the ability to distort markets and unafraid to engage in regulatory capture. MNEs came in just two flavors, European and North American MNEs, with the Japanese as the primary exception (Bartlett and Ghoshal, 1989; Prahalad and Doz, 1987).

Time matters, because sociological, political and economic trends shift. Somewhere between the 1980s to the 1990s the idea that firms primarily engaged in FDI to support trade became passé, and within that time, the rapid expansion of Japanese and European MNEs made it clear that these firms were acquiring assets for reasons only secondarily associated with trade enhancement, and more to augment their firm-specific advantages (FSAs). Japanese MNEs also introduced us to the idea of transplants and the idea of multiple tiers of suppliers and production networks and cross-border value chains (not as yet global). Europe as an important political and economic bloc went from fantasy to reality, and the USSR imploded and the remaining countries became classified as part of the developing world. China becoming the largest economy in the world seemed implausible just twenty years ago.

The era in which the issue of internationalization motives began to matter to IB reflects that this was a time where trade theory reigned supreme, and mainstream trade theory had a strongly neoclassical pedigree. That is to say, John Dunning (like many others) was 
addressing an audience of neo-classical economists, and that epistemic community required the discussion to be couched in that community of practice, and their assumptions (Narula, 2010). Therefore, the motivations of MNEs reflected rational managers, who had access to plenty of information that allowed them to make fully informed economic choices. Scale economies were a paramount objective, and FDI reflected market imperfections; once these imperfections were corrected, the cause of FDI instead of trade would disappear. In short, the steady state was trade, and FDI was evidence of disequilibrium.

Today, such assumptions seem not only rather antiquated, but also unnecessary. IB and economics are increasingly distant cousins, and we do not have to couch arguments in the prevalent economics narrative to survive the review process. Even mainstream economists have taken to different paradigms that do not require such restrictive assumptions. Managers are no longer expected to be rational (or even boundedly rational), and we do not expect that their decision making will be precise and prescient. We now believe that firms do not always maximize, because firms and their managers are not fully rational, and they cannot possibly have full information of all the alternatives.

The IB literature has also come around to the troublesome realization that not all managers evaluate risk in the same way. Behavioral Economics and regulatory focus theory show us that managers' experiences and attitudes towards risk vary considerably. Some individuals seek to minimize losses more so than maximize returns, and these play a role in their decision to take their firm abroad (see Cuervo-Cazurra et al., 2015 in this issue). Moreover, we can no longer assume that the same individuals will always make the same choices because experience with previous outcomes modifies their perspectives and decision making. Positive outcomes lead managers to assume that it was their prescience and ability, rather than luck or 
the environment that led to success. This leads them to undertake additional risks, and develop hubris, which can have nefarious consequences later on. Negative outcomes lead managers to become more cautious in their decisions, unless they are faced with the extreme situation in which they become willing to make one big bet to get out of the hole, even if such action sinks their company. Moreover, their experience dealing with institutions at home also modify their ability to deal with risk, as managers in emerging markets become accustomed at operating under high levels of uncertainty and develop higher flexibility and adaptability in decision making than their counterparts in advanced economies (Cuervo-Cazurra, 2012).

\section{Changes in our understanding of motives}

These changes in the real world and in the world of ideas have led to a rethinking of internationalization motives. These include the rethinking of location advantage, intra- and inter-firm interactions, developmental implications and the relevance of particular motives.

The importance of location advantages and the change in motives

As Benito (2015 in this issue) notes, the 'classic motives' are deliberately about internationalization (and serve little purpose in understanding other activities of the firm). Decisions about internationalization mean that the reasons for a particular investment are associated with access (or lack thereof) of location-bound resources in the host country. These may be firm-specific, if they are owned by, and available exclusively to specific economic actors, in which case they are FSAs. They may be available in principle to all firms physically or legally domiciled in the host country (such as those associated with knowledge infrastructure, or natural resources) in which case they are location advantages (Narula and Santangelo, 2012). 
This is important, because it helps understand the differences between the strategy of a firm and its motivation to internationalize. It may be your strategy to do certain things, amongst which one may be to internationalize, but to decide on a specific location requires the logic of location advantages to be included in the decision. The motivation to internationalize implies that the MNE seeks to utilize its FSAs in conjunction with location-specific assets. A motive depends crucially upon the presence or absence of location advantages, and this is often lost in the way in which the concept of motivations is used in the literature. FSAs and location advantages interact, shape and influence the nature of each other in future periods (Narula, 2012). They are not an alternative to a classification of possible strategies.

\section{The relevance of theory-driven motives}

One of the biggest problems is that motives literature may bear little relationship to reality as a manager might understand them. This reflects the poverty of the kinds of research tools we utilize to perform our field work. As van Tulder (2015 in this issue) observes, when managers are given a finite number of theoretically derived choices of motives, they react with bemusement. For a variety of reasons to do with competition and rivalry, firms are unable or unwilling to divulge what their true motives might be for a particular investment decision. Being truthful may have costs, most immediately and obviously with tax authorities or a host government ('we are taking your subsidies because we are only interested in your country as a means to reduce our tax bill at home'), or home countries ('we are reducing our employment at home unless you incentivize us to stay').

Nonetheless, decision making is rarely easily reduced to simple discrete choices. Firms have mixed-motives, and serially evolving motives, motives that are less important, and others that become more important. Firms may have multiple establishments in one location, each of 
which is engaged in different activities for different reasons. Even within a specific firm the various headquarters-subsidiary relationships will change over time. Some subsidiaries may become more strategically significant, while others become less so.

However, simplicity-through-stylization is a useful tool for empirical analysis, and provides the average reader the tools to understand what otherwise is a study in opacity. CuervoCazurra et al. (2015 in this issue) suggest, using a theoretical lens, that the large diaspora of motives can be simplified into four conceptually-driven 'envelopes'; the last column in Table I links these four envelopes with the nine Dunning motives.

\section{Strategic asset seeking as a motivation}

Perhaps one of the most troublesome of motives is strategic asset-seeking. Dunning's definition was (intentionally) broad. It can be read either as 'the acquisition of assets that are 'strategic', as well as 'the seeking of assets for strategic reasons'. As we have noted earlier, Dunning (1993) included a broad array of what we consider to be asset-augmenting activity as an aspect of resource-seeking investments, since arguably technological assets are resources as well. As several authors in this forum note, 'asset-seeking' has become a 'catchall' motivation, because rare is the firm that does not want to augment its assets, or to improve its competitiveness. As Meyer (2015 in this issue) notes, various scholars have used alternative terms such as asset-augmenting to distinguish between the broad definition, and the precise meaning they wish the term to imbue. This lack of precision is not entirely accidental. Indeed, Dunning and Narula (1995) specifically (and also intentionally) used the concept of asset-seeking to refer only to the acquisition of technological assets through FDI in $R \& D$ facilities, which was different from its use in other contemporaneous publications by Dunning; others consider the acquisition of any kind of assets to be strategic by definition. 
Unfortunately, when strategic asset seeking is used in such a wide variety of ways, it becomes tautological - all activities are strategic in some way (rare is the manager who will admit that there was no strategy in a particular action!), and in the limit there is no decision that cannot correctly be said to be the 'seeking of assets' of some sort. As Benito (2015 in this issue) observes, asset-seeking is forward-looking (and aspirational), and more than any other foreign activity of an MNE, depends upon the correct appraisal of the assets of other external actors (Narula and Santangelo, 2012).

\section{The problems of intra-firm and inter-firm interaction and evolving motives}

Since we are now in a world where MNE, is not simply a synonym for FDI, this also requires us to reconsider internationalization motives. In the case of inter-firm relationships, these result in the existence of multiple motives within the same activity. MNEs are engaged abroad in intermediate forms of governance that require ongoing and interactive cooperation with other firm actors, whether suppliers, competitors or customers. Collaboration is a complex activity that requires matching and adjusting expectations and outputs of multiple actors. Research on collaboration indicate that more than half of all such ventures are considered to be failures by at least one partner (Reuer and Zollo, 2005) often because of what is termed 'unfulfilled expectations'. The challenge in part is that partners have limited incentives to reveal their true 'intrinsic' motives, especially where the collaborator may suffer some loss by the achievement of these objectives (Narula and Martinez-Noya, 2015).

In the case of intra-MNE relationships, there are differences in motives between units of the same MNE. It is no longer the case (or at least, we recognize now that it is not the case) that subsidiaries are passive extensions of the parent firm, and subservient to the will of 
headquarters. The modern MNE acts more as a federation with 'an on-going power contest' between the various units (Ambos et al., 2010) reflecting an uneasy balancing act between the quest for greater autonomy by the subsidiary against a centralising tendency by HQ (see Holm and Pedersen, 2000; Birkinshaw and Hood, 1998). MNEs use 'coopetition' to improve efficiency, and this means that subsidiaries can be organized in complex structures that can accelerate or impede knowledge flows within the MNE (Narula, 2014). It also means that the strategy of two subsidiaries within the same MNE can differ, and the motives of the headquarters in undertaking certain actions may not be implemented by the foreign subsidiary (Athreye et al., 2014).

Motives, therefore, are always evolving, like strategies, because they are aspirational, and when they fail to produce the desired outcome, require a revision in motivation, if not also in strategy. But crucially, they are also dependent upon actors exogenous to the firm for their successful implementation. These actors are not passive, and also have their own motivations which are also evolving. Relationships are rarely equal, and this can mean that firms in a weaker position (such as suppliers to large MNEs) have their internationalization strategies dictated to them by their customers, or sometimes by their competitors. Arguably, the state of the MNE is still in considerable flux. A number of MNEs are organized in traditional hierarchies that involve FDI and wholly-owned subsidiaries, while simultaneously also being integrated in a complex web of non-equity relationships and interdependencies between and amongst a variety of other actors (Giroud and Mirza, 2015 in this issue).

\section{Developmental implications of motives}

Governments often have MNE-based development strategies that drive incentives and subsidies intended to achieve certain net welfare benefits. Thus, they have their own motives 
for making particular location advantages available to specific MNEs. When the two sets of motivations are aligned, Pareto-optimal outcomes become possible. When they differ, an uneasy relationship exists between the MNE and the government (Stopford and Strange, 1992; Vernon, 1977). In addition, though, governmental development objectives change over time, which can result in conflict with the MNE.

There is a tendency by both academics and policy makers to seek specific types of FDI, and for this there has been increasing reliance on FDI motives as a classification to identify desirable types of FDI (Narula and Dunning, 2000, 2010). While it is true that certain kinds of MNE activity may have greater welfare effects than others, the use of the motives classification as a means of judging the potential benefits of particular types of FDI can be misjudged. On the one hand, motives per se have no or little use in determining the relative merits of investments, and simply to set targets of how much 'asset-seeking' investment a country needs to attract or encourage, is to stretch the concept of normative policy to the extreme (as the Chinese state has begun to explicitly do; Luo et al., 2010). On the other hand, since motives are about the interaction of FSAs with location advantages, if the MNE's investment motives are gauged accurately it is possible to evaluate the potential for upgrading, and the kinds of location advantages that industrial policy needs to focus on upgrading.

Two papers in this forum focus on different aspects of policy. Pananond (2015 in this issue) explains how the motives of internationalization need to be rethought when analyzing emerging market multinationals (EMNCs). It argues that the weak position of firms and their integration in global value chains modify the selection of motives in several ways. First, the youth of EMNCs as multinationals and their limited resources as a result of the 
underdevelopment of their countries of origin result in new dynamics in the selection of motives. Second, the integration of EMNCs in global value chains in which firms in countries with low cost factors of production, such as emerging countries, internationalize initially and indirectly as suppliers of firms from advanced countries provides new insights into motives. The driver of upgrading or moving up in the value chain and the smile curve (Mudambi, 2008) alter the usual selection of motives. The level of development of the host country plays an important role, because some of the entries in advanced economies are not only market but strategic asset seeking (Madhok and Keyhani, 2012), which may not likely happen for entries in other emerging markets.

Giroud and Mirza (2015 in this issue) analyze the motivations for FDI under a global value chain (GVC) perspective, adding depth to the arguments presented by Pananond (2015 in this issue). They provide a broad historical evolution of the motives that highlights the role of the broader economy as a driver of motives, and how advances in technology and liberalization have facilitated this evolution of motives of advanced economy MNCs. The emergence of GVCs has altered our understanding of these motives, because MNEs from advanced economies have created the GVCs by training suppliers and subcontracting to them in other countries, or by telling domestic suppliers to accompany them abroad. GVCs have also been facilitated by improvements in the contracting environment in emerging economies and the general reduction of transaction costs, as well as the development of countries and increasing sophistication of factors of production (e.g. R\&D in emerging economies is now feasible because of the improvement in education). This has resulted in a more nuanced understanding of the types of strategic asset seeking, with a distinction between the objective and the feasibility in achieving the objective. 


\section{Conclusions}

There is no logical or conceptual reason for the IB community to remain bound by the artificial constraint that the MNE is driven primarily by four seeking motivations, three of which are based on exploiting existing assets, and one that is angled towards exploration of assets. That these particular motives remain primary, and the others are 'secondary' has no basis in theory (Cuervo-Cazurra et al., 2015 in this issue). Indeed the concept of internationalization motives is somewhat atheoretical, in the sense that - like the eclectic paradigm - it provides a toolkit that permits its use (or disuse) in conjunction with other theories and frameworks. Its value is greatest when used in conjunction with other frameworks. Like the eclectic paradigm, it has thrived because it allows for complex issues to be simplified. Like the eclectic paradigm, it suffers from being read as dogma, unchanging and inflexible. Its purpose, again like the eclectic paradigm, was to be a guide to providing order to an increasingly complex universe. Dunning's motives were not forged as a set of immutable laws, by a prescient authority in the fires of Mordor: they were a function of the period, and reflected the background and knowledge of particular scholars, their biases and their preferences.

To further belabor the metaphor from J.R.R. Tolkien's Lord of the Ring saga: Should there be a set of motives to rule them all? The answer we propose is 'yes'. Whether it is practical to do so is another matter entirely. Cuervo-Cazurra et al. (2015 in this issue) propose such a unifying set, and for obvious reasons the authors of this paper are inclined to recommend it to all the races of Middle-Earth. But we recognize that it reflects the research interests and objectives of its authors, and provides clarity for their purposes (and those of like-minded scholars). Without travelling far, it is clear from the views expressed by van Tulder (2015 in 
this issue), or Giroud and Mirza (2015 in this issue), that the Cuervo-Cazurra fellowship may not satisfy the needs of all scholars.

We ordered the accompanying articles to this special issue in a sequence that may help better understand internationalization motives and how to interpret them. First, Benito provides an overview of the importance of the analysis of internationalization motives in his article "Why and how motives (still) matter." Second, we have two articles providing alternative classifications of motives, one by Cuervo-Cazurra et al. titled "Internationalization motives: sell more, buy better, upgrade and escape" and another by van Tulder titled "Getting all motives right: a holistic approach to internationalization motives of companies". Finally, we have three articles providing nuanced discussions of internationalization motives, with Meyer's article "What is 'strategic asset seeking FDI'?" presenting a deep discussion of one of the motives; Giroud and Mirza's article "Refining of FDI motivations by integrating global value chains' considerations" explaining how global supply chains alter internationalization motives; and Pananond's article "Motives for foreign direct investment: an emerging market multinational's perspective" discussing how the analysis of emerging market multinationals modifies internationalization motives. Each of the articles provides its own contribution and the seven articles as a set provide a deeper understanding of internationalization motives that we hope will renew the interests on this topic, as well as result in additional research extending and improving the arguments presented in this forum.

\section{Notes}

1. See also Hymer (1968) which remains pretty much ignored.

2. An earlier draft of the 1993 book included 'trade-supportive investments as the fifth 'main' motive. This version informed the 1993 doctoral thesis of Rajneesh Narula (later published as Narula, 1996) and is included in his dissertation as one of the five main motives of international production.

\section{References}


Ambos, T.C., Andersson, U. and Birkinshaw, J. (2010), "What are the consequences of initiative-taking in multinational subsidiaries?", Journal of International Business Studies, Vol. 41 No.7, pp. 1099-118.

Athreye, S., Celikel, A. and Ujjual, V. (2014), "Internationalisation of R\&D into emerging markets: Fiat's R\&D in Brazil, Turkey and India", Long Range Planning, Vol. 47 No. 1-2, pp. 100-114.

Bartlett, C. A., and Ghoshal, S. (1999), Managing Across Borders: The Transnational Solution, Harvard Business School Press, Boston, MA.

Benito, G. (2015), "Why and how motives (still) matter", Multinational Business Review, Vol. 23 No. 1, in this issue.

Birkinshaw, J. and Hood, N. (1998), "Multinational subsidiary evolution: capability and charter change in foreign-owned subsidiary companies", Academy of Management Review, Vol. 23, No. 4, pp. 773-95.

Cuervo-Cazurra, A. (2012), "Extending theory by analysing developing country multinational companies: solving the goldilocks debate", Global Strategy Journal, Vol. 2 No. 33, pp.153-67.

Cuervo-Cazurra, A., and Ramamurti, R. (2014), "Conclusion: an agenda for future research", in Cuervo-Cazurra, A., and Ramamurti, R. (Eds.), Understanding Multinationals from Emerging Markets, Cambridge University Press, Cambridge, UK, pp.271-300.

Cuervo-Cazurra, A., Narula, R. and Un, C.A. (2015), "Internationalization motives: sell more, buy better, upgrade and escape", Multinational Business Review, Vol. 23 No.1, in this issue.

Dunning, J. H. (1988), Explaining International Production, Harper Collins Academic. London, UK.

Dunning, J. H. (1993), Multinational Enterprises and the Global Economy, Addison-Wesley, Wokingham, UK.

Dunning, J. H., and Lundan, S. M. (2008), Multinational Enterprises and the Global Economy, Edward Elgar Publishing, Cheltenham, UK.

Dunning, J. and Narula, R. (1995), "The R\&D activities of foreign firms in the United States", International Studies of Management \& Organization, Vol. 25 No. 1-2, pp. 39-73.

Giroud, A. and Mirza, H. (2015), "Refining of FDI motivations by integrating global value chains' considerations", Multinational Business Review, Vol. 23 No. 1, in this issue.

Held, D., McGrew, A., Goldblatt, D. and Perraton, J. (1999), Global Transformations. Politics, Economics and Culture, Polity Press, Cambridge, UK.

Holm, U. and Pedersen, T., (2000), The Emergence and Impact of MNC Centres of Excellence: A Subsidiary Perspective, MacMillan, London, UK.

Hymer, S.H. (1968), “The large multinational 'corporation': an analysis of some motives for the international integration of business", Revue Économique Vol. 19 No. 6, pp. 94973.

Kojima, K. (1978), Direct Foreign Investment: A Japanese Model of Multinational Business Operations, Croom Helm, London, UK.

Luo, Y., Xue, Q., and Han, B. (2010), "How emerging market governments promote outward FDI: experience from China", Journal of World Business, Vol. 45 No.1, pp. 68-79.

Madhok, A., and Keyhani, M. (2012), "Acquisitions as entrepreneurship: asymmetries, opportunities, and the internationalization of multinationals from emerging economies", Global Strategy Journal, Vol. 2 No.1, pp. 26-40.

Meyer, K. (2015), "What is 'strategic asset seeking FDI'"?, Multinational Business Review, Vol. 23 No. 1, in this issue. 
Mudambi, R. (2008), "Location, control and innovation in knowledge-intensive industries", Journal of Economic Geography, Vol. 8 No.5, pp. 699-725.

Narula, R. (1996), Multinational Investment and Economic Structure, Routledge, London, UK.

Narula, R. (2003), Globalisation and Technology: Interdependence, Innovation Systems and Industrial Policy, Polity Press, Cambridge, UK.

Narula, R. (2010), "Keeping the eclectic paradigm simple”, Multinational Business Review, Vol. 18 No.2, pp. 35-50.

Narula, R. (2012), "Do we need different frameworks to explain infant MNEs from developing countries?", Global Strategy Journal, Vol.2 No.3, pp. 188-204.

Narula, R. (2014), "Exploring the paradox of competence-creating subsidiaries: balancing bandwidth and dispersion in MNEs", Long Range Planning, Vol. 47 No.1-2, pp. 4-15.

Narula, R., and Dunning, J. H. (2000), "Industrial development, globalization and multinational enterprises: new realities for developing countries", Oxford Development Studies, Vol. 28 No. 2, pp.141-67.

Narula, R., and Dunning, J. H. (2010), "Multinational enterprises, development and globalization: some clarifications and a research agenda", Oxford Development Studies, Vol.38 No. 3, pp.263-87.

Narula, R., and Martinez-Noya A. (2015), "International R\&D alliances by firms: origins and development", in Archibugi, D. and Filipetti, A (Eds.), The Handbook of Global Science, Technology, and Innovation, Wiley-Blackwell, Hoboken, NJ.

Narula, R. and Santangelo, G. D. (2012), "Location and collocation advantages in international innovation", Multinational Business Review, Vol.20 No.1, pp.6-25.

Pananond, P. (2015), "Motives for foreign direct investment: an emerging market multinational's perspective", Multinational Business Review, Vol. 23 No. 1, in this issue.

Pitelis, C. and Sugden, R. (2000), The Nature of the Transnational Firm, Psychology Press, London, UK.

Prahalad, C. K., and Doz, Y. L. (1999), The Multinational Mission: Balancing Local Demands and Global Vision, Simon and Schuster, New York, NY.

Reich, R. (1990), "Who is us", Harvard Business Review, Vol. 68 No. 1, pp.53-64

Reuer, J., and Zollo, M. (2005), "Termination outcomes of research alliances", Research Policy, Vol. 34 No.1, pp. 101-15.

Stopford, J. and Strange, S. (1991), Rival States, Rival Firms. Competition for World Market Shares, Cambridge University Press, Cambridge, UK.

van Tulder, R. (2015), "Getting all motives right: a holistic approach to internationalization motives of companies", Multinational Business Review, Vol. 23 No. 1, in this issue.

Vernon, R. (1977), Storm Over the Multinationals: The Real Issues, Harvard University Press, Cambridge, MA. 